\title{
Pengaruh Kepemimpinan Dan Motivasi Terhadap Kinerja Karyawan Pada PT. Niaga Bangun Persada Di Jakarta
}

\author{
${ }^{1}$ Aris Baharuddin, ${ }^{2}$ Rudi Salam \\ ${ }^{1.2}$ Department of Administration Science, Faculty of Social Sience, \\ Universitas Negeri Makassar \\ Email : aris.baharuddin@unm.ac.id, 2rudisalam@unm.ac.id
}

\begin{abstract}
ABSTRAK
Penelitian ini bertujuan untuk mengetahui pengaruh kepemimpinan dan motivasi terhadap kinerja karyawan pada PT. Niaga Bangun Persada di Jakarta.

Metode yang digunakan adalah explanatory research dengan teknik analisis menggunakan analisis statistik dengan pengujian regresi, korelasi, determinasi dan uji hipotesis.

Hasil penelitian ini kepemimpinan berpengaruh signifikan terhadap kinerja karyawan sebesar 41,4\%, uji hipotesis diperoleh $t$ hitung $>t$ tabel atau $(6,510>$ $2,000)$. Motivasi berpengaruh signifikan terhadap kinerja karyawan sebesar 37,2\%, uji hipotesis diperoleh $\mathrm{t}$ hitung $>\mathrm{t}$ tabel atau $(5,957>2,000)$. Kepemimpinan dan motivasi secara simultan berpengaruh signifikan terhadap kinerja karyawan dengan persamaan regresi $\mathrm{Y}=9,588+0,392 \mathrm{X} 1+0,385 \mathrm{X} 2$ dan kontribusi pengaruh sebesar $53,0 \%$, uji hipotesis diperoleh $\mathrm{F}$ hitung $>\mathrm{F}$ tabel atau $(33,317>2,760)$.
\end{abstract}

Kata Kunci: Kepemimpinan, Motivasi, Kinerja Karyawan. 


\section{PENDAHULUAN}

Perubahan lingkungan dalam sebuah organisasi semakin kompleks dan kompetitif, menuntut sebuah organisasi untuk lebih responsif agar terus bertahan dan berkembang. Dalam kehidupan sehari-hari manusia tidak pernah lepas dari kehidupan berorganisasi, karena pada kodratnya manusia merupakan mahluk sosial yang cenderung bermasyarakat. Dalam hal itu kita manusia juga merupakan mahluk yang saling bersosialisasi.

Berbagai bidang khususnya kehidupan berorganisasi, faktor manusia merupakan masalah utama di setiap kegiatan yang ada di dalamnya. Organisasi adalah suatu kerangka hubungan yang berstruktur yang didalamnya berisi wewenang, tanggung jawab dan pembagian kerja untuk menjalankan sesuatu fungsi tertentu. Setiap tindakan dan aktivitas dalam sebuah organisasi ditentukan oleh manusia yang ada dalam wilayah organisasi tersebut. Setiap organisasi membutuhkan faktor sumber daya manusia yang potensial baik itu pemimpin maupun karyawan yang masing-masing memiliki peran dan tugas yang merupakan penentu tercapainya tujuan organisasi.

Berdasarkan latar belakang masalah yang telah diuraikan, dapat kita ketahui bahwa manusia merupakan sumber daya yang paling mempengaruhi dalam mencapai tujuan organisasi. Permasalahan dalam organisasi ini adalah tinggi rendahnya kepemimpinan dan motivasi kerja karyawan. Kinerja, motivasi dan kepemimpinan karyawan yang tinggi sangatlah diharapkan oleh organisasi tersebut. Produktifitas dan hasil kinerja sanga dipengaru oleh kinerja yang efektif dan tinggi sehingga organisasi tersebut mampu memberikan hasil terbaik untuk menunjang eksporimpor. Kinerja karyawan Dewan Kawasan dapat diukur melalui penyelesaian tugasnya secara efektif dan efsien serta melakukan peran dan fungsinya dan itu semua berhubunga linea dan berhubungan positif bagi keberhasilan suatu organisasi.

Pada sebuah organisasi terdapat sebuah struktur atau unsur sederhana yaitu pemimpin sebagai atasan, dan karyawan/karyawan sebagai bawahan. Seorang pemimpin sangatlah penting dalam menjalankan tugas dan perannya di dalam sebuah organisasi. Visi, misi dan tujuan organisasi pun tidak akan terwujud bila seorang pemimpin yang menghendaki. Seorang pemimpin harus mempunyai dan memperlihatkan gaya kepemimpinannya. Setiap pemimpin mempunyai gaya dan cara memimpin yang berbeda-beda. Kepemimpinan seorang pemimpin mampu membuat karyawannya berprestasi dan memberikan hasil dan kinerja terbaik. Motivasi adalah dorongan, upaya dan keinginan yang ada di dalam diri manusia yang mengaktifkan, memberi daya serta mengarahkan perilaku untuk melaksanakan tugastugas dengan baik dalam lingkup pekerjaannya, Hakim dalam Regina (2010).

Berdasarkan pengertian di atas dapat disimpulkan bahwa motivasi dapat dipandang sebagai fungsi, berarti motivasi berfungsi sebagai daya penggerak dari dalam individu untuk melakukan aktivitas tertentu dalam mencapai tujuan. 


\section{RUMUSAN MASALAH}

Dari uraian latar belakang permasalahan, maka masalah yang diteliti selanjutnya dapat dirumuskan sebagai berikut :

1. Adakah pengaruh secara parsial antara kepemimpinan terhadap kinerja karyawan pada PT. Niaga Bangun Persada di Jakarta?.

2. Adakah pengaruh secara parsial antara motivasi terhadap kinerja karyawan pada PT. Niaga Bangun Persada di Jakarta?.

3. Adakah pengaruh secara simultan antara kepemimpinan dan motivasi terhadap kinerja karyawan pada PT. Niaga Bangun Persada di Jakarta?

\section{KAJIAN TEORI \\ KEPEMIMPINAN}

Menurut Kartono (2011)

pengertian kepemimpinan yaitu kegiatan atau seni mempengaruhi orang lain agar mau bekerjasama yang didasarkan pada kemampuan orang tersebut untuk membimbing orang lain dalam mencapai tujuantujuan yang diinginkan kelompok. Kepemimpinan hanya dapat dilaksanakan oleh seorang pemimpin. Seorang pemimpin adalah seseorang yang mempunyai keahlian memimpin, mempunyai kemampuan mempengaruhi pendirian/pendapat orang atau sekelompok orang tanpa menanyakan alasan- alasannya. Seorang pemimpin adalah seseorang yang aktif membuat rencana-rencana, mengkoordinasi, melakukan percobaan dan memimpin pekerjaan untuk mencapai tujuan bersamasama. Pengaruh seorang pemimpin dalam sebuah lembaga atau organisasi menentukan himbauan serta tujuan untuk mencapai visi dan misi.

\section{MOTIVASI}

Gaya kepemimpinan adalah suatu bakat yang diperoleh orang sebagai kemampuan istimewa yang dibawa sejak lahir.

\section{KINERJA}

Motivasi merupakan suatu kondisi yang mendorong atau menjadikan sebab seseorang dicapai oleh karyawan dalam pekerjanya menurut kriteria tertentu yang berlaku untuk suatu pekerjan. Dari pernyataan di atas maka dapat ditarik kesimpulan bahwa kinerja karyawan merupakan suatu tingkat kemajuan seorang karyawan atas hasil dari usahanya untuk meningkatkan kemampuan secara positif dalam pekerjaannya Pada dasarnya seorang karyawan dalam melaksanakan tugas yang dibebankan kepadanya diharapkan untuk menunjukkan suatu performance yang terbaik yang bisa ditunjukkan oleh karyawan tersebut, selain itu performance yang ditunjukan oleh seorang karyawan tentu saja dipengaruhi oleh berbagai fakor yang penting artinya bagi peningkatan hasil kerja yang menjadi tujuan dari organisasi atau instansi di mana karyawan tersebut bekerja

\section{KINERJA KARYAWAN}

Menurut pendapat Rivai (2008), kinerja merupakan kesediaan seseorang atau kelompok orang untuk melakukan suatu kegiatan dan menyempurnakannya sesuai dengan tanggung jawab dan hasil seperti yang diharapkan. Anwar (2006) mengemukakan kinerja karyawan 
merupakan prestasi kerja, yakni perbandingan antara hasil kerja yang dapat dilihat secara nyata dengan standar kerja yang telah ditetapkan organisasi. Kemudian Robins (2008) mendefinisikan kinerja yaitu suatu hasil yang Kelima aspek tersebut dapat dijadikan ukuran dalam mengadakan pengkajian tingkat kinerja seseorang.

\section{HASIL PENELITIAN DAN PEMBAHASAN}

1. Analisis Deskriptif

Pada pengujian ini digunakan untuk mengetahui skor minimum dan maksimum, mean score dan standar deviasi dari masingmasing variabel. Adapun hasilnya sebagai berikut:

Tabel Hasil Analisis Descriptive Statistics

\begin{tabular}{|c|c|c|c|c|c|}
\hline \multicolumn{7}{|c|}{ Descriptive Statistics } \\
\hline Kepemimpinan (X1) & N & Minimum & Maximum & Mean & Std. Deviation \\
\hline Motivasi (X2) & 62 & 31 & 48 & 37.89 & 4.208 \\
\hline Kinerja Karyawan (Y) & 62 & 31 & 45 & 38.27 & 3.676 \\
\hline Valid N (listwise) & 62 & & 46 & 39.18 & 3.628 \\
\hline
\end{tabular}

Kepemimpinan diperoleh varians minimum sebesar 31 dan varians maximum 48 dengan mean score sebesar 3,79 dengan standar deviasi 4,208. Motivasi diperoleh varians minimum sebesar 31 dan varians maximum 45 dengan mean score sebesar 3,83 dengan standar deviasi 3,676. Kinerja karyawan diperoleh varians minimum sebesar 33 dan varians maximum Coefficients $^{a}$

\begin{tabular}{|c|c|c|c|c|c|}
\hline \multirow[b]{2}{*}{ Model } & \multicolumn{2}{|c|}{$\begin{array}{l}\text { Unstandardized } \\
\text { Coefficients }\end{array}$} & \multirow{2}{*}{$\begin{array}{l}\text { Standardized } \\
\text { Coefficients } \\
\text { Beta }\end{array}$} & \multirow[b]{2}{*}{$\mathrm{t}$} & \multirow[b]{2}{*}{ Sig. } \\
\hline & $\mathrm{B}$ & Std. Error & & & \\
\hline (Constant) & 9.588 & 3.690 & & 2.598 & .012 \\
\hline Kepemimpinan (X1) & .392 & .088 & .455 & 4.466 & .000 \\
\hline Motivasi (X2) & .385 & .101 & .390 & 3.825 & .000 \\
\hline
\end{tabular}

a. Dependent Variable: Kinerja Karyawan (Y)

Berdasarkan hasil pengujian pada tabel di atas, diperoleh persamaan regresi $\mathrm{Y}=9,588+$ $0,392 \mathrm{X} 1+0,385 \mathrm{X} 2$. Dari persamaan tersebut dijelaskan sebagai berikut:

1) Konstanta sebesar 9,588 diartikan jika kepemimpinan dan motivasi tidak ada, maka
46 dengan mean score sebesar 3,92 dengan standar deviasi 3,628

\section{Analisis Verifikatif}

Pada analisis ini dimaksudkan untuk mengetahui pengaruh variabel independen terhadap variabel dependen. Adapun hasil pengujian sebagai berikut:

a. Analisis Regresi Linier Berganda 
mengalami peningkatan sebesar 0,392 point.

3) Koefisien regresi motivasi sebesar 0,385, angka ini positif artinya setiap ada peningkatan motivasi sebesar 0,385 maka kinerja karyawan juga akan mengalami peningkatan sebesar 0,385 point.

b. Analisis Koefisien Korelasi

Analisis koefisien korelasi dimaksudkan untuk mengetahui Correlations $^{\text {b }}$

\begin{tabular}{lll|l} 
& & $\begin{array}{l}\text { Kepemim } \\
\text { pinan }(\mathrm{X} 1)\end{array}$ & $\begin{array}{l}\text { Kinerja } \\
\text { Karyawan (Y) }\end{array}$ \\
\hline $\begin{array}{l}\text { Kepemimpinan } \\
(\mathrm{X} 1)\end{array}$ & $\begin{array}{l}\text { Pearson } \\
\text { Correlation }\end{array}$ & 1 & $.643^{\text {** }}$ \\
\cline { 2 - 4 } & Sig. (2-tailed) & & .000 \\
\hline $\begin{array}{l}\text { Kinerja } \\
(\mathrm{Y})\end{array}$ & $\begin{array}{l}\text { Pearson } \\
\text { Caryawan }\end{array}$ & $.643^{\text {}}$ & 1 \\
\cline { 2 - 4 } & Sig. (2-tailed) & .000 & \\
\hline
\end{tabular}

Berdasarkan hasil pengujian diperoleh nilai korelasi sebesar 0,643 artinya kepemimpinan tingkt kekuatan hubungan dari variabel independen terhadap variabel dependen baik secara parsial maupun simultan. Adapun hasil pengujian sebagai berikut:

Tabel 3. Hasil Pengujian Koefisien Korelasi Kepemimpinan Terhadap Kinerja Karyawan

memiliki hubungan yang kuat terhadap kinerja karyawan.

Tabel Hasil Pengujian Koefisien Korelasi Motivasi Terhadap Kinerja Karyawan.

Correlations $^{\text {b }}$

\begin{tabular}{lll|l} 
& & $\begin{array}{l}\text { Motivasi } \\
(\mathrm{X} 2)\end{array}$ & $\begin{array}{l}\text { Kinerja } \\
\text { Karyawan (Y) }\end{array}$ \\
\hline Motivasi (X2) & $\begin{array}{l}\text { Pearson } \\
\text { Correlation }\end{array}$ & 1 & $.610^{* *}$ \\
\cline { 2 - 4 } & Sig. (2-tailed) & & .000 \\
\hline $\begin{array}{l}\text { Kinerja } \\
(\mathrm{Y})\end{array}$ & $\begin{array}{l}\text { Pearson } \\
\text { Correlation }\end{array}$ & $.610^{* *}$ & 1 \\
\hline & Sig. (2-tailed) & .000 & \\
\hline
\end{tabular}

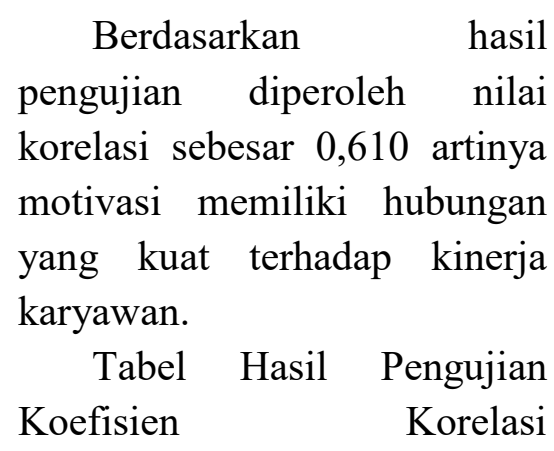

Kepemimpinan dan Motivasi secara simultan Terhadap Kinerja Karyawan 


\begin{tabular}{|c|c|c|c|c|}
\hline \multicolumn{5}{|c|}{ Model Summary } \\
\hline $\begin{array}{l}\text { Mo } \\
\text { del }\end{array}$ & $\mathrm{R}$ & R Square & $\begin{array}{l}\text { Adjusted } \\
\text { R Square }\end{array}$ & $\begin{array}{l}\text { Std. Error of the } \\
\text { Estimate }\end{array}$ \\
\hline 1 & $.728^{a}$ & .530 & .514 & 2.528 \\
\hline
\end{tabular}

a. Predictors: (Constant), Motivasi (X2), Kepemimpinan (X1)

Berdasarkan hasil pengujian diperoleh nilai korelasi sebesar 0,728 artinya kepemimpinan dan motivasi secara simultan memiliki hubungan yang kuat terhadap kinerja karyawan.

c. Analisis Koefisien Determinasi

Analisis koefisien determinasi dimaksudkan untuk mengetahui Model Summary

\begin{tabular}{|c|c|c|c|c|}
\hline $\begin{array}{l}M \\
1\end{array}$ & $\mathrm{R}$ & R Square & $\begin{array}{l}\text { Adjusted } \\
\text { Square }\end{array}$ & $\begin{array}{l}\text { Std. Error of the } \\
\text { Estimate }\end{array}$ \\
\hline 1 & $.643^{\mathrm{a}}$ & .414 & .404 & 2.801 \\
\hline
\end{tabular}

Berdasarkan hasil pengujian diperoleh nilai determinasi sebesar 0,414 artinya kepemimpinan memiliki kontribusi pengaruh sebesar besarnya persentase pengaruh dari variabel independen terhadap variabel dependen baik secara parsial maupun simultan. Adapun hasil pengujian sebagai berikut:

Tabel Hasil Pengujian Koefisien Determinasi Kepemimpinan Terhadap Kinerja Karyawan
$41,4 \%$ terhadap kinerja karyawan.

Tabel 7. Hasil Pengujian Koefisien Determinasi Motivasi Terhadap Kinerja Karyawan

\begin{tabular}{|c|c|c|c|c|}
\hline \multicolumn{5}{|c|}{ Model Summary } \\
\hline Model & $\mathrm{R}$ & R Square & $\begin{array}{l}\text { Adjusted R } \\
\text { Square }\end{array}$ & $\begin{array}{l}\text { Std. Error of the } \\
\text { Estimate }\end{array}$ \\
\hline 1 & $.610^{\mathrm{a}}$ & .372 & .361 & 2.900 \\
\hline
\end{tabular}

Berdasarkan hasil pengujian diperoleh nilai determinasi sebesar 0,372 artinya motivasi memiliki kontribusi pengaruh sebesar $37,2 \%$ terhadap kinerja karyawan.

\begin{tabular}{l|r|cr|r} 
& \multicolumn{2}{c}{ Model Summary } \\
Model & \multicolumn{2}{c}{$\begin{array}{c}\text { Adjusted R } \\
\text { Std. Error of the } \\
\text { Estimate }\end{array}$} \\
\hline 1 & R Square & Square & \multicolumn{2}{c}{2.528} \\
\hline a. Predictors: (Constant), Motivasi (X2), Kepemimpinan (X1)
\end{tabular}

Tabel Hasil Pengujian Koefisien Determinasi Kepemimpinan dan Motivasi Terhadap Kinerja Karyawan. 
Berdasarkan hasil pengujian diperoleh nilai determinasi sebesar 0,530 artinya kepemimpinan dan motivasi secara simultan memiliki kontribusi pengaruh sebesar $53,0 \%$ terhadap kinerja karyawan, sedangkan sisanya sebesar $47,0 \%$ dipengaruhi faktor lain.

\section{Uji Hipotesis}

\begin{tabular}{|c|c|c|c|c|c|c|}
\hline \multirow{2}{*}{\multicolumn{2}{|c|}{ Model }} & \multicolumn{2}{|c|}{$\begin{array}{l}\text { Unstandardized } \\
\text { Coefficients }\end{array}$} & \multirow{2}{*}{$\begin{array}{c}\text { Standardized } \\
\text { Coefficients } \\
\text { Beta }\end{array}$} & \multirow[b]{2}{*}{$\mathrm{t}$} & \multirow[b]{2}{*}{ Sig. } \\
\hline & & B & Std. Error & & & \\
\hline \multirow[t]{2}{*}{1} & (Constant) & 18.160 & 3.248 & & 5.591 & .000 \\
\hline & Kepemimpinan (X1) & .555 & .085 & .643 & 6.510 & .000 \\
\hline
\end{tabular}

Uji hipotesis Parsial (Uji t)

Pengujian hipotesis dengan uji $t$ digunakan untuk mengetahui hipotesis parsial mana yang diterima.

Hipotesis pertama: Terdapat pengaruh yang signifikan antara kepemimpinan terhadap kinerja karyawan.

Tabel Hasil Uji Hipotesis Kepemimpinan Terhadap Kinerja Karyawan.

a. Dependent Variable: Kinerja Karyawan (Y)

Berdasarkan hasil pengujian pada tabel di atas, diperoleh nilai $\mathrm{t}$ hitung $>\mathrm{t}$ tabel atau $(6,510>2,000)$, dengan demikian hipotesis pertama yang

\begin{tabular}{llr|rr|r|r} 
& \multicolumn{2}{c}{$\begin{array}{c}\text { Coefficients } \\
\text { Unstandardized } \\
\text { Model }\end{array}$} & \multicolumn{2}{c}{$\begin{array}{c}\text { Standardized } \\
\text { Coefficients }\end{array}$} & & \\
\hline Coefficients & & & \\
(Constant) & $\mathrm{B}$ & Std. Error & Beta & $\mathrm{t}$ & \multicolumn{1}{c}{ Sig. } \\
\hline Motivasi (X2) & 16.149 & 3.884 & & 4.158 & .000 \\
\hline
\end{tabular}

a. Dependent Variable: Kinerja Karyawan (Y)

Berdasarkan hasil pengujian pada tabel di atas, diperoleh nilai $t$ hitung $>\mathrm{t}$ tabel atau $(5,957>2,000)$, dengan demikian hipotesis kedua yang diajukan bahwa terdapat pengaruh yang signifikan atara motivasi terhadap kinerja karyawan diterima.

Uji Hipotesis Simultan (Uji F) diajukan bahwa terdapat pengaruh yang signifikan atara kepemimpinan terhadap kinerja karyawan diterima.

\begin{tabular}{ll|r|r|r|r|r}
\multirow{2}{*}{ Model } & & \multicolumn{2}{c}{ ANOVA $^{\mathbf{a}}$} & \multicolumn{1}{c}{ F } & \multicolumn{1}{c}{ Sig. } \\
\hline 1 & Regression & 425.922 & 2 & 212.961 & 33.317 & $.000^{\mathrm{b}}$ \\
\cline { 2 - 8 } & Residual & 377.127 & 59 & 6.392 & & \\
\cline { 2 - 8 } & Total & 803.048 & 61 & & & \\
\hline
\end{tabular}


Berdasarkan hasil pengujian pada tabel di atas, diperoleh nilai $\mathrm{F}$ hitung $>$ F tabel atau $(33,317>2,760)$, dengan demikian hipotesis ketiga yang diajukan bahwa terdapat pengaruh yang signifikan atara kepemimpinan dan motivasi terhadap kinerja karyawan diterima.

\section{PEMBAHASAN}

PENELITIAN

\section{Pengaruh}

Terhadap Kinerja Karyawan

Kepemimpinan berpengaruh signifikan terhadap kinerja karyawan dengan korelasi sebesar 0,643 atau memiliki hubungan yang kuat dengan kontribusi pengaruh sebesar $41,4 \%$. Pengujian hipotesis diperoleh nilai $\mathrm{t}$ hitung $>\mathrm{t}$ tabel atau $(6,510>2,000)$. Dengan demikian hipotesis pertama yang diajukan bahwa terdapat berpengaruh signifikan antara kepemimpinan terhadap kinerja karyawan diterima.

\section{Pengaruh Motivasi Terhadap Kinerja Karyawan \\ Motivasi berpengaruh} signifikan terhadap kinerja karyawan dengan korelasi sebesar 0,610 atau memiliki hubungan yang kuat dengan kontribusi pengaruh sebesar $37,2 \%$. Pengujian hipotesis diperoleh nilai $\mathrm{t}$ hitung $>\mathrm{t}$ tabel atau $(5,957>2,000)$. Dengan demikian hipotesis kedua yang diajukan bahwa terdapat berpengaruh signifikan antara motivasi terhadap kinerja karyawan diterima.

\section{Pengaruh Kepemimpinan dan Motivasi Terhadap Kinerja Karyawan}

Kepemimpinan dan motivasi berpengaruh signifikan terhadap kinerja karyawan dengan diperoleh persamaan regresi $\mathrm{Y}=9,588+$ $0,392 \times 1+0,385 X 2$, nilai korelasi sebesar 0,728 atau memiliki hubungan yang kuat dengan kontribusi pengaruh sebesar $53,0 \%$ sedangkan sisanya sebesar $47,0 \%$ dipengaruhi faktor lain. Pengujian hipotesis diperoleh nilai $\mathrm{F}$ hitung $>\mathrm{F}$ tabel atau $(33,317>2,760)$. Dengan demikian hipotesis ketiga yang diajukan bahwa terdapat berpengaruh signifikan antara kepemimpinan dan motivasi terhadap kinerja karyawan diterima.

\section{KESIMPULAN DAN SARAN}

\section{A. Kesimpulan}

1. Kepemimpinan berpengaruh signifikan terhadap kinerja karyawan dengan kontribusi pengaruh sebesar $41,4 \%$. Uji hipotesis diperoleh nilai t hitung $>\mathrm{t}$ tabel atau $(6,510>2,000)$.

2. Motivasi berpengaruh signifikan terhadap kinerja karyawan dengan kontribusi pengaruh sebesar 37,2\%. Uji hipotesis diperoleh nilai t hitung $>$ t tabel atau $(5,957>2,000)$.

3. Kepemimpinan dan motivasi berpengaruh signifikan terhadap kinerja karyawan dengan kontribusi pengaruh sebesar $53,0 \%$ sedangkan sisanya sebesar $\quad 47,0 \%$ dipengaruhi faktor lain. $\mathrm{Uji}$ hipotesis diperoleh nilai $\mathrm{F}$ hitung $>$ F tabel atau $(33,317>$ $2,760)$.

\section{B. Saran}

1. Pimpinan harus menegakkan peraturan dengan baik sesuai dengan ketentuan yang berlaku guna menjamin 
karyawan diperlakukan dengan adil.

2. Perusahaan harus selalu memberikan semangat dan apresiasi yang layak untuk memastikan karyawan memiliki semangat kerja yang tinggi.

3. Kinerja perusahaan dapat ditingkatkan dengan memberdayakan karyawan dengan menegakkan peraturan yang baik dan pemberian motivasi yang lebih inten lagi.

\section{DAFTAR PUSTAKA}

Algifari. (2015). "Analisis Regresi untuk Bisnis dan Ekonomi". Yogyakarta: BPFE.

Arikunto, Suharsimi (2014). "Prosedur Penelitian Suatu Pendekatan Praktek". Jakarta: Rineka Cipta.

D Sunarsi. (2020). Kepemimpinan Bisnis Strategik. Kota Serang: Desanta Muliavisitama

Edi Sutrisno (2016). Manajemen Sumber Daya Manusia. Jakarta: Prenadamedia Group.

Freed Luthans (2016) Organizational Behavior, McGraw-Hill, New York.

Gerry Dessler (2016) Human Resources Management, Prenticehall, London: International Inc.

Handoko (2016) Manajemen Personalia dan Sumberdaya Manusia. Yogyakarta: BPFE.

Hasibuan (2016) "Manajemen Sumber Daya Manusia”. Haji Masagung. Jakarta.

Henry Simamora (2005), Manajemen Sumber Daya Manusia, STIE YKPN Bandung.
Imam Ghozali (2017). “Aplikasi Analisis Multivariate Dengan Program SPSS”. Edisi Kelima. Semarang: Badan Penerbit Undip.

Istijanto (2014) "Riset Sumber Daya Manusia". Jakarta: PT. Gramedia Pustaka

Jasmani, J. (2019). Pengaruh Product Development Dan Promotion Mix Terhadap Peningkatan Penjualan Yang Berdampak Pada Keunggulan Bersaing. Jurnal Ekonomi Efektif, 1(2).

Jasmani, J., \& Sunarsi, D. (2020). The Influence of Product Mix, Promotion Mix and Brand Image on Consumer Purchasing Decisions of Sari Roti Products in South Tangerang. PINISI Discretion Review, 1(1), 165174.

Kartini Kartono (2011) Pemimpin dan Kepemimpinan, Jakarta: PT. Rajawaligrafindo Persada.

Mangkunegara, Anwar Prabu, 2008. "Manajemen Sumber Daya Manusia Perusahaan, cetakan pertama". Penerbit: Remaja Rosdakarya, Bandung

Mani, J. (2018). Pengaruh Peran Nilai Pelanggan Dan Citra Merek Terhadap Kinerja Pemasaran. Jurnal Mandiri, 2(2), 263-280.

Nitisemito, Alek.S, (2010), Manajemen Personalia, Ghalia Indonesia, Jakarta.

Pranoto, P., Jasmani, J., \& Marayasa, I. N. (2019). Pelatihan Digital Marketing Untuk Peningkatan Perekonomian Anggota Karang Taruna Al Barkah Di Kampung Cicayur-Tangerang. Jurnal Pengabdian Dharma Laksana, 1(2), 250-258. 
Rao, Purba, (2012). "Measuring Consumer Perceptions Through Factor Analysis", The Asian.

Rivai Veithzal (2015) Manajemen Sumber Daya Manusia Untuk Perusahaan. Jakarta: PT Raja Grafindo Persada.

Rozi, A., \& Sunarsi, D. (2020). The Influence of Motivation and Work Experience on Employee Performance at PT. Yamaha Saka Motor in South Tangerang. Jurnal Office, 5(2), 65-74.

Santoso, Singgih (2015). "Menguasai Statistik Multivariat”. Jakarta: PT Elex Media Komputindo.

Sedarmayanti (2016) Manajemen Sumber Daya Manusia, Reformasi Birokrasi dan Manajemen Karyawan Negeri Sipil, Cetakan Kelima, Bandung: PT Refika Aditama.

Siagian, S (2007). Manajemen Sumber Daya Manusia. Jakarta: Bumi Aksara.

Sinamo, J. (2011). Delapan Etos Kerja Profesional. Jakarta: Institut

Sudjana (2014) “Metode Statistika”, Bandung: Tarsido.

Sugiyono (2017), "Metode Penelitian Administrasi : dilengkapi dengan Metode $R \& D$ ". Bandung: Alfabeta.

Sunarsi, D. (2018). Buku Ajar: Seminar Perencanaan Sumber Daya Manusia. Tangerang Selatan: Asmoro Mediatama

Sunarsi, D. (2018). Buku Ajar: Seminar Perencanaan Sumber Daya Manusia. Tangerang Selatan: Asmoro Mediatama

Sunarsi, D. (2018). Pengembangan Sumber Daya Manusia
Strategik \& Karakterisrik Sistem Pendukungnya : Sebuah Tinjauan. Jurnal Ilmiah MEA (Manajemen, Ekonomi, \& Akuntansi), 2(3), 178 - 194.

Sunyoto. 2016. Metodologi Penelitian Akuntansi. Bandung: PT Refika Aditama.

Suwanto, S. (2019). Pengaruh Disiplin Kerja Dan Motivasi Kerja Terhadap Kinerja Karyawan Pada Rumah Sakit Umum Tangerang Selatan. JENIUS, 3(1), 16-23.

Suwanto, S. (2019). Pengaruh Gaya Kepemimpinan Dan Lingkungan Kerja Terhadap Kinerja Karyawan Unit Telesales Pada PT BFI Finance Indonesia TBK. Jurnal Ekonomi Efektif, 1(2).

Thoha. 2013. Kepemimpinan dan Manajemen. Jakarta : PT Raja Grafindo

Yukl. 2015. Kepemimpinan Dalam Organisasi (Edisi 7). Jakarta : Indeks 